\title{
Biochemical markers decrease and increase disproportionally in A1 pulley tissue of type 2 diabetic trigger finger patients
}

\author{
Tip 2 diyabetik tetik parmak hastalarında A1 pulley dokusunda biyokimyasal belirteçler \\ orantısız olarak azalır ve artar
}

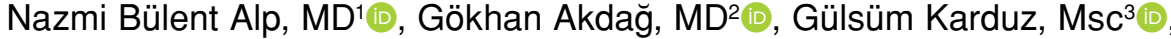 \\ Kübra Vardar, $\mathrm{MSc}^{3}$ (D) Uğur Aksu, $\mathrm{Phd}^{3}$ (D)
}

\begin{abstract}
'Department of Orthopedics and Traumatology, Istanbul Bahçelievler State Hospital, Istanbul, Turkey 2Department of Orthopedics and Traumatology, Istanbul Beylikdüzü State Hospital, Istanbul, Turkey

${ }^{3}$ Department Biology, Istanbul University, Science Faculty, Istanbul, Turkey
\end{abstract}

\begin{abstract}
Objectives: This study aims to detect the levels of some biochemical markers in A1 pulley tissue of type 2 diabetic trigger finger patients to enlighten the mechanisms leading to cellular complications.
\end{abstract}

Patients and methods: The study included 35 trigger finger patients (5 males, 30 females; mean age $53.9 \pm 9.15$ years; range, 37 to 71 years). We measured total thiol (total-SH) levels to determine the status of the non-enzymatic antioxidant defense system and advanced oxidation protein product (AOPP) levels to determine levels of oxidative protein modification in pulley tissues of trigger finger patients with or without diabetes. Extracellular matrix degradation was assessed by measuring levels of sialic acid (SA) in the pulley tissue.

Results: Total-SH values for the groups with and without diabetes were $22.7 \pm 1.6$ vs. $38.9 \pm 5.2 \mathrm{nmol} / \mathrm{mg}$ protein, respectively, while AOPP values were $472.5 \pm 131.6$ vs. $175.6 \pm 9.9 \mathrm{mmol} / \mathrm{g}$ protein, respectively. The SA levels of diabetic and nondiabetic patients were $0.4 \pm 0.0$ vs. $0.63 \pm 0.1 \mathrm{nmol} / \mathrm{mg}$ protein, respectively.

Conclusion: Our results revealed that tissue SA levels and tissue SH levels decreased and AOPP levels increased disproportionally in the A1 pulley tissue of diabetic patients, which may indicate the role of oxidative protein damage and extracellular matrix changes in diabetic trigger finger etiology.

Keywords: A1 pulley, advanced oxidation protein product, oxidative protein damage, sialic acid, trigger finger, type 2 diabetes.

\section{ÖZ}

Amaç: Bu çalışmada hücresel komplikasyonlara yol açan mekanizmaları aydınlatmak için tip 2 diyabetik tetik parmak hastalarında A1 pulley dokusunda bazı biyokimyasal belirteçlerin düzeyleri saptand.

Hastalar ve yöntemler: Çalışmaya 35 tetik parmak hastası (5 erkek, 30 kadın; ort. yaş $53.9 \pm 9.15$ yıl; dağılım, 37-71 yıl) dahil edildi. Enzimatik olmayan antioksidan savunma sisteminin durumunu belirlemek için total tiyol (total-SH) düzeyleri, oksidatif protein modifikasyon düzeylerini belirlemek için gelişmiş oksidasyon protein ürünü (AOPP) düzeyleri diyabetli ve diyabetli olmayan tetik parmak hastalarının pulley dokularında ölçüldü. Hücre dışı matriks bozulması pulley dokusundaki sialik asit (SA) düzeylerinin ölçülmesiyle değerlendirildi.

Bulgular: Diyabetli ve diyabetli olmayan gruplar için total-SH değerleri sırasıla $22.7 \pm 1.6$ 'ya karşı $38.9 \pm 5.2 \mathrm{nmol} / \mathrm{mg}$ protein iken AOPP değerleri sırasıyla 472.5 \pm 131.6 'ya karş1 $175.6 \pm 9.9 \mathrm{mmol} / \mathrm{g}$ protein idi. Diyabetik ve diyabetik olmayan hastaların SA düzeyleri sırasıyla $0.4 \pm 0.0$ 'e karşı $0.6 \pm 0.1 \mathrm{nmol} / \mathrm{mg}$ protein idi.

Sonuç: Bulgularımız diyabetik hastaların A1 pulley dokularında doku SA düzeylerinin ve doku $\mathrm{SH}$ düzeylerinin azaldığını ve AOPP düzeylerinin orantısız olarak arttığını ortaya koyarak diyabetik tetik parmak etyolojisinde oksidatif protein hasarı ve hücre dışı matriks değişikliklerinin rolüne işaret etmektedir.

Anahtar sözcükler: A1 pulley, gelişmiş oksidasyon protein ürünü, oksidatif protein hasar1, sialik asit, tetik parmak, tip 2 diyabet.

Received: March 21, 2019 Accepted: May 15, 2019 Published online: June 13, 2019

Correspondence: Nazmi Bülent Alp, MD. Uludağ Üniversitesi Tıp Fakültesi Ortopedi ve Travmatoloji Anabilim Dalı, 16059 Görükle, Bursa, Turkey. Tel: +90533 - 5182057 e-mail: nazmibulentalp@hotmail.com 
Tendon is a fibrous connective tissue that attaches muscle to bone. Tendons enable motion of a hand; the flexor tendons are surrounded by the annular and cruciate pulleys. As a result of unknown etiology, inflammation and irritation may lead to thickening and narrowing of the A1 pulley around its underlying flexor tendon. ${ }^{[1]}$ This condition causes a mismatch between the diameter of the flexor tendons and the A1 pulley leading to fastening, catching and pain at the level of the metacarpophalangeal joint during both flexion and extension. ${ }^{[1]}$

Although trigger finger is one of the most frequently seen entrapment tendinopathies, the etiology and pathogenesis are not entirely understood. Trigger finger cases have been reported with an incidence ranging from $1.7 \%$ to $2.6 \%$ in a healthy population. ${ }^{[2,3]}$ The prevalence of trigger finger disease increases up to $4 \%$ to $29 \%$ in the diabetic population. ${ }^{[4,5]}$

Sampson et al., ${ }^{[1]}$ performed a comparative study of A1 pulleys, including histological, immunochemical, and transmission electron microscopic evaluations of normal and trigger finger. The authors proposed that fibrocartilage metaplasia could be an important mechanism for A1 pulley degeneration. However, the exact biochemical mechanism in the extracellular matrix and the redox balance that contribute to the occurrence of fibrocartilage metaplasia in diabetic patients have not been published or even investigated. Therefore, in this study, we aimed to detect the levels of some biochemical markers in A1 pulley tissue of type 2 diabetic trigger finger patients to enlighten the mechanisms leading to cellular complications.

\section{PATIENTS AND METHODS}

This prospective cohort study was conducted at Istanbul Bahçelievler State Hospital between June 2017 and October 2017 and included 35 trigger finger patients (5 males, 30 females; mean age 53.9 \pm 9.15 years; range, 37 to 71 years). We measured total thiol (total-SH) levels to determine the status of the nonenzymatic antioxidant defense system and advanced oxidation protein product (AOPP) levels to determine levels of oxidative protein modification in the pulley tissues of trigger finger patients with or without diabetic conditions. Furthermore, extracellular matrix degradation was assessed by measuring levels of sialic acid (SA) in pulley tissue. The study protocol was approved by the University of Health Science, Bakırköy Dr. Sadi Konuk Training and Research Hospital Ethics Committee (No: 2017-06-46). A written informed consent was obtained from each patient. The study was conducted in accordance with the principles of the Declaration of Helsinki.
We used the Quinnell ${ }^{[6]}$ classification system for trigger finger (Table I). We only studied type 2 diabetes because type 2 is the most common (95\%) form of diabetes; only $5 \%$ of patients have type 1 diabetes. The inclusion criterion was having no benefit from conservative treatment, such as splinting or injection, for at least six months. We excluded patients younger than 18 years, who had a tendon sheath tumor or any other soft tissue mass that mimics trigger finger, or who had a combined disease such as Dupuytren's disease or de Quervain's tenosynovitis in the same hand. Patients with grade 0 or grade I according to Quinnell's classification were excluded. All patients were assigned into the nondiabetic or diabetic group according to criteria published by the World Health Organization $^{[7]}$ in 2003. Eighteen patients were controlled with oral anti-diabetic drugs, and patients were controlled with diet.

Trigger finger surgery was performed under local anesthesia. By transverse incision and blunt dissection, the A1 pulley was identified, and the largest-diameter portion of the pulley was resected. Pulley tissues were evaluated for biochemical purposes. After resection, the patients were asked to attempt active full flexion and extension of the finger to confirm the resolution of triggering.

Pulley tissue samples were frozen at $-20^{\circ} \mathrm{C}$ immediately following collection until homogenization occurred. The homogenization procedure was performed mechanically in $10 \%$ (weight/volume) homogenizing buffer $(100 \mathrm{mM}$ KH2PO4·K2HPO4, $\mathrm{pH}$ 7.4).

Thiols, also known as mercaptans, are organic compounds that contain a sulfhydryl group $(-\mathrm{SH})$, which is composed of a sulfur atom and a hydrogen atom attached to a carbon atom. ${ }^{[8]}$ The plasma thiol pool is mostly composed of albumin thiols and protein thiols, with the remainder of the pool composed of low-molecular-weight thiols such as cysteine (Cys), cysteinylglycine, glutathione, homocysteine, and gamma-glutamylcysteine. ${ }^{[9]}$ Thiols (RSH) can undergo

TABLE I

Quinnell classification system for trigger finger

\begin{tabular}{cl}
\hline Grade & Clinical findings (during flexion and extension) \\
\hline 0 & Normal movement \\
I & Uneven movement \\
II & Actively correctable \\
III & Passively correctable \\
IV & Fixed deformity \\
\hline
\end{tabular}


oxidation reactions via oxidants and form disulfide (RSSR) bonds. ${ }^{[10]}$ A disulfide bond is a covalent bond; the linkage is also called an disulphide bond or disulfide bridge. Under conditions of oxidative stress, the oxidation of Cys residues can lead to the reversible formation of mixed disulfides between protein thiol groups and low-molecular-mass thiols. The disulfide bonds that are formed can again be reduced to thiol groups; thus, dynamic thiol-disulfide homeostasis is maintained ${ }^{[11]}$ Dynamic thiol-disulfide homeostasis has a critical role in antioxidant protection, detoxification, signal transduction, apoptosis, regulation of enzymatic activity and transcription factors and in cellular signaling mechanisms. ${ }^{[12,13]}$

Moreover, dynamic thiol-disulfide homeostasis is being increasingly implicated in many disorders. ${ }^{[14-17]}$ There is also an increasing body of evidence demonstrating that an abnormal thioldisulfide homeostasis state is involved in the pathogenesis of a range of diseases, including diabetes, ${ }^{[14]}$ cardiovascular disease, ${ }^{[15]}$ cancer, ${ }^{[16]}$ and rheumatoid arthritis, ${ }^{[17]}$ Therefore, the determination of dynamic thiol-disulfide homeostasis can provide valuable information on various normal or abnormal biochemical processes.

The total-SH assay was performed according to Sedlak and Lindsay's method. ${ }^{[18]}$ The tissue samples were put into test tubes with $0.2 \mathrm{M}$ Tris buffer


acid). The mixture was brought to $1 \mathrm{~mL}$ by adding absolute methanol. Reagent and sample blanks were prepared similarly. All solutions were incubated for 15 minutes and then centrifuged at 3,000 $\mathrm{g}$ at room temperature for 15 minutes. The absorbance of the supernatant fractions was measured at $412 \mathrm{~nm}$ by a spectrophotometer.

Advanced oxidation protein products arise from the reaction between plasma proteins and chlorinated oxidants (e.g., hypochlorous acid) by the hydrogen peroxide-myeloperoxidase system and are di-tyrosinecontaining cross-linking protein products considered to be novel markers of oxidant-mediated protein damage. ${ }^{[19-21]}$ Advanced oxidation protein products are commonly carried by albumin in the circulation, and oxidized albumin is rapidly cleared mainly through uptake by the liver and spleen. ${ }^{[22]}$ Similar to advanced glycation end products (AGEs), AOPPs signal via the receptor for AGE in endothelial cells and induce endothelial dysfunction. ${ }^{[23]}$ Elevated plasma levels of AOPPs have been found in many diseases, such as diabetes, uremia, obesity, coronary artery disease, and inflammatory bowel diseases. Evidence indicates that AOPP levels increase with age and that AOPPs can trigger cytosolic superoxide generation via the activation of nicotinamide adenine dinucleotide phosphate oxidase, which is a main source of reactive oxygen species (ROS). ${ }^{[24]}$ Therefore, AOPPs may serve not only as markers of oxidant-mediated protein damage but also as potential inducers of oxidative stress. ${ }^{[21]}$

Advanced oxidation protein product levels were determined by oxidized protein status. A slightly modified method of Hanasand et al. ${ }^{[25]}$ was used for spectrophotometric determination of AOPP levels. According to the current procedure, the tissue samples were diluted with acetic acid and $1.16 \mathrm{M}$ potassium iodide was added to the diluted solution. The absorbance of the solution was read against the blank solution (at $340 \mathrm{~nm}$ ) using a spectrophotometer. The AOPP levels are presented as micromoles per liter of chloramine-T equivalents.

Among the glycoconjugates, SA is present in up to $30 \%$ in various glycoproteins. ${ }^{[26]}$ The cell coat is made up of predominantly SA-containing glycoproteins. ${ }^{[27]}$ Sialic acid plays an important role in cell-cell recognition, cell permeability, cell adhesion, and immunogenicity. ${ }^{[28]}$

The SA concentration was determined according to Sydow's modified method. ${ }^{[29]}$ Perchloric acid was added to tissue homogenate samples. Following incubation at $100^{\circ} \mathrm{C}$ for five minutes, the mixtures were centrifuged at 2,500 $\mathrm{g}$ for four minutes. The obtained supernatants were added to Ehrlich's reagent and incubated at $100^{\circ} \mathrm{C}$ for five minutes. After distilled water was added to the mixtures, the absorbance was measured at $525 \mathrm{~nm}$ using a spectrophotometer.

During this study, we used the manual colorimetric method as a measurement method. To the best of our knowledge, there are no normal values published in the literature regarding pulley tissue AOPP, SA or thiol levels. We compared normal pulley tissue and diabetic pulley tissue and tried to understand whether they had any differences.

\section{Statistical analysis}

Datasets were presented as the mean \pm standard deviation. Statistical analysis was performed with GraphPad Prism version 5.0 for Windows (GraphPad Software Inc., San Diego, CA, USA). The unpaired one-tailed t-test was conducted for the statistical comparison. A significance level of $\mathrm{p}<0.05$ was considered as statistically significant.

\section{RESULTS}

The mean ages of diabetic and nondiabetic patients were $53.2 \pm 10.4$ and $54.6 \pm 7.9$ years, 
TABLE II

Finger involvement

\begin{tabular}{lcc}
\hline & Diabetic & Nondiabetic \\
\hline Thumb & 10 & 8 \\
Index & 5 & 2 \\
Middle & 2 & 4 \\
Ring & 2 & 1 \\
Small & 1 & 0 \\
\hline
\end{tabular}



Figure 1. Total thiol level graph.

T-SH: Total thiol; ND: Nondiabetic; D: Diabetic.

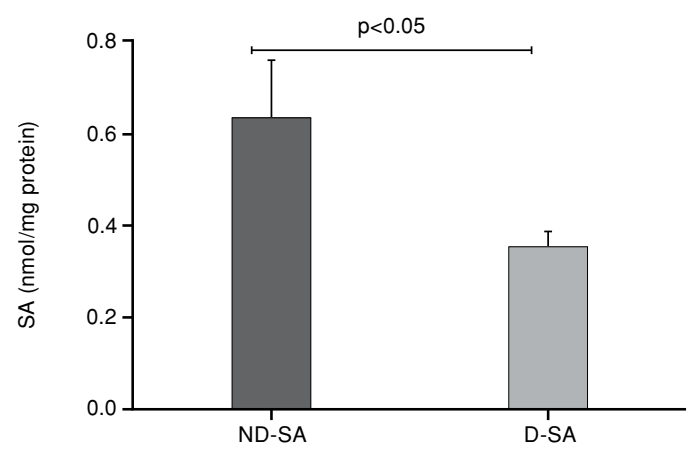

Figure 2. Sialic acid level graph. SA: Sialic acid; ND: Nondiabetic; D: Diabetic.

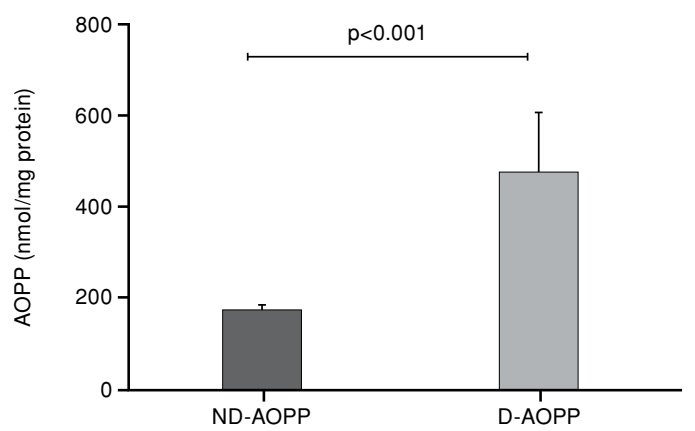

Figure 3. Advanced oxidation protein product level graph.

AOPP: Advanced oxidation protein product; ND: Nondiabetic; D: Diabetic. respectively. The total number of patients in the type 2 diabetic group was 20 (3 males, 17 females). The nondiabetic group consisted of 15 patients ( 2 males, 13 females). The dominant hand was the involved hand in 28 patients, and the nondominant hand was the involved hand in seven patients. The finger involved was as follows in diabetes patients: thumb $=10$, index $=5$, middle $=2$, ring $=2$, and small $=1$. Thumb $=8$, index $=2$, middle $=4$, ring $=1$, and small $=0$ was the finger involvement distribution for the nondiabetic patients (Table II).

Total-SH levels in pulley tissues were significantly decreased in diabetic patients when compared to nondiabetic patients $(22.7 \pm 1.6$ vs. $38.9 \pm 5.2 \mathrm{nmol} / \mathrm{mg}$ protein, respectively; $\mathrm{p}<0.05)$ (Figure 1). Tissue SA levels were also decreased in diabetic patients when compared to nondiabetic patients $(0.35 \pm 0.03$ vs. $0.6 \pm 0.12 \mathrm{nmol} / \mathrm{mg}$ protein, respectively; $\mathrm{p}<0.05$ ) (Figure 2). However, when we measured the tissue AOPP levels, they were increased in diabetic patients in contrast to nondiabetic patients: $472.5 \pm 131.6$ vs. $175.6 \pm 9.9 \mathrm{mmol} / \mathrm{g}$ protein, respectively, $\mathrm{p}<0.05$ (Figure 3).

\section{DISCUSSION}

The present study aimed to determine the effect of diabetes on oxidative protein damage and extracellular matrix changes between diabetic and nondiabetic pulley tissues. Type 2 diabetes leads to pulley tissue protein modifications and oxidative stress. These changes accompany cellular surface changes. To our knowledge, there is no in vivo investigation concerning the oxidative damage of diabetes in patients with trigger finger in the hand surgery literature. ${ }^{[30]}$

Strom 3 promoted the association between trigger finger and diabetes mellitus. Moreover, some researchers ${ }^{[31,32]}$ have shown that the trigger finger cases seen in diabetic patients have lower responses to surgery or to nonsurgical treatment than those in nondiabetic patients. It is not precisely clear why the surgical procedure or the conservative treatment is less favorable for patients with diabetes.

Our findings showed that pulley tissue $\mathrm{SH}$ was significantly decreased in patients with diabetes. As we know from the literature, it has already been shown that free radicals cause oxidation of protein $\mathrm{SH}$ groups. All of the $\mathrm{SH}$ moieties are protein associated. Protein $\mathrm{SH}$ groups can serve as an antioxidant by various mechanisms. Protein SHs scavenge ${ }^{[33]}$ peroxidation initiators and thus protect lipid membranes from attack. The $\mathrm{SH}$ moieties 
are thought to project a balance between the cells' release of a sulfhydryl-containing protein due to increased cellular activity and the plasma oxidation reactions. ${ }^{[34]}$ We compared the $\mathrm{SH}$ levels in diabetic and nondiabetic pulley tissues in our study. We did not focus on the plasma $\mathrm{SH}$ level for oxidative tissue damage because the plasma $\mathrm{SH}$ levels due to oxidative damage of other tissues in diabetic patients may not specify the pulley damage. We focused on tissue $\mathrm{SH}$ levels. In a study performed with diabetic rats, $\mathrm{SH}$ groups proved to be useful as the total peroxyl radical-trapping antioxidant measurement parameter. ${ }^{[35]}$ It is important to emphasize that diabetes-induced ROS elevation may result in decreased total cellular/tissue SH levels. ${ }^{[3]}$

We observed that SA levels are decreased in diabetic patients when compared with nondiabetic patients. Sialic acid acts as a cofactor for many cell surface receptors. ${ }^{[37]}$ The unique structural feature of SA, which contains a negative charge due to a carboxyl group, provides a vital role in cellular functions such as cell-cell repulsion, recognition, transport of positively charged compounds, and tumor cell metastasis. Although we found decreased tissue SA levels, details on the modulation of SA metabolism between various organs under insulin resistance or chronic hyperglycemic conditions are insufficient. In their experimental study, Ibrahim et al. ${ }^{[38]}$ found decreased pancreatic SA levels in high-glucosefed rats when compared to the healthy group, but high fructose and glucose feeding did not affect SA levels in the muscle and heart. In the kidney and liver, they observed significantly increased SA levels in both the high-fructose and glucose feeding groups. Crook et al. ${ }^{[39]}$ showed that total serum SA is a newly established potential risk factor for the development of macro- and microvascular complications of diabetes. In the present study, AOPPs, which are another biochemical parameter, were high when compared to those in diabetic patients. Advanced oxidation protein products are defined as tyrosine containing cross-linked protein products that formed during oxidative stress and are considered to be a reliable marker of protein oxidation. Diabetic patients have lower antioxidant capacity than healthy individuals. Advanced oxidation protein products are recognized as one of the possible markers of oxidative stress that originates under oxidative and carbonyl stress and that increase global inflammatory activity. Recent papers ${ }^{[40]}$ suggest that AOPPs are not only a marker of oxidative stress but also act as inflammatory mediators. Some authors concluded that the AOPP level seems to be a useful marker to estimate the degree of oxidative protein damage in diabetic patients. ${ }^{[4]}$ Additionally, AOPPs are formed during oxidative stress by the action of chloramines produced by myeloperoxidase in activated neutrophils. These compounds (advanced glycation end products and AOPPs) accumulate in biological systems and thus take part in longterm diabetic complications by causing damage to biological membranes and endothelium. ${ }^{[42]}$

There are several limitations to this study. First, our sample size was small, while the detection of significant differences suggests that the present study is sufficiently powered, although a power analysis was not performed. Second, more than $90 \%$ of patients (both in the diabetic and nondiabetic groups) received corticosteroid injection before surgery. It is almost impossible to catch pure trigger finger patients who did not receive any conservative treatment (i.e., corticosteroid, platelet rich plasma). We do not know the exact effect of corticosteroid on the A1 pulley. If nearly all patients received this treatment, the treatment's effect may occur equally in both groups, and thus have minimal impact on the results of our study. Another limitation is that we did not collect any normal tissue outside of the A1 pulley tissue from either group. The question we were addressing was regarding the biochemical effect of diabetes on the pulley tissue. For this reason, we examined pulley tissue only.

In conclusion, our results indicated that biochemical markers decreased and increased disproportionally in the diabetic A1 pulley tissue, and we think that this may be relevant in trigger finger etiology in diabetic patients. Although our results may not clarify all the questions concerning the etiology of trigger finger, they may assist in understanding why the prevalence of trigger finger patients is high in the type 2 diabetic population.

\section{Declaration of conflicting interests}

The authors declared no conflicts of interest with respect to the authorship and/or publication of this article.

\section{Funding}

The authors received no financial support for the research and/or authorship of this article.

\section{REFERENCES}

1. Sampson SP, Badalamente MA, Hurst LC, Seidman J. Pathobiology of the human A1 pulley in trigger finger. J Hand Surg Am 1991;16:714-21.

2. Renard E, Jacques D, Chammas M, Poirier JL, Bonifacj C, Jaffiol $C$, et al. Increased prevalence of soft tissue hand 
lesions in type 1 and type 2 diabetes mellitus: various entities and associated significance. Diabete Metab 1994;20:513-21.

3. Strom L. Trigger finger in diabetes. J Med Soc N J 1977;74:951-4.

4. Freiberg A, Mulholland RS, Levine R. Nonoperative treatment of trigger fingers and thumbs. J Hand Surg Am 1989;14:553-8.

5. Ramchurn N, Mashamba C, Leitch E, Arutchelvam V, Narayanan K, Weaver J, et al. Upper limb musculoskeletal abnormalities and poor metabolic control in diabetes. Eur J Intern Med 2009;20:718-21.

6. Quinnell RC. Conservative management of trigger finger. Practitioner 1980;224:187-90.

7. Expert Committee on the Diagnosis and Classification of Diabetes Mellitus. Report of the expert committee on the diagnosis and classification of diabetes mellitus. Diabetes Care 2003;26:5-20.

8. Sen CK, Packer L. Thiol homeostasis and supplements in physical exercise. Am J Clin Nutr 2000;72:653-69.

9. Turell L, Radi R, Alvarez B. The thiol pool in human plasma: the central contribution of albumin to redox processes. Free Radic Biol Med 2013;65:244-53.

10. Cremers CM, Jakob U. Oxidant sensing by reversible disulfide bond formation. J Biol Chem 2013;288:26489-96.

11. Jones DP, Liang Y. Measuring the poise of thiol/disulfide couples in vivo. Free Radic Biol Med 2009;47:1329-38.

12. Biswas S, Chida AS, Rahman I. Redox modifications of protein-thiols: emerging roles in cell signaling. Biochem Pharmacol 2006;71:551-64.

13. Circu ML, Aw TY. Reactive oxygen species, cellular redox systems, and apoptosis. Free Radic Biol Med 2010;48:749-62.

14. Matteucci E, Giampietro O. Thiol signalling network with an eye to diabetes. Molecules 2010;15:8890-903.

15. Go YM, Jones DP. Cysteine/cystine redox signaling in cardiovascular disease. Free Radic Biol Med 2011;50:495509.

16. Prabhu A, Sarcar B, Kahali S, Yuan Z, Johnson JJ, Adam KP, et al. Cysteine catabolism: a novel metabolic pathway contributing to glioblastoma growth. Cancer Res 2014;74:787-96.

17. Tetik S, Ahmad S, Alturfan AA, Fresko I, Disbudak M, Sahin $Y$, et al. Determination of oxidant stress in plasma of rheumatoid arthritis and primary osteoarthritis patients. Indian J Biochem Biophys 2010;47:353-8.

18. Sedlak J, Lindsay RH. Estimation of total, protein-bound, and nonprotein sulfhydryl groups in tissue with Ellman's reagent. Anal Biochem 1968;25:192-205.

19. Hazen SL, Hsu FF, Heinecke JW. p-Hydroxyphenylacetaldehyde is the major product of L-tyrosine oxidation by activated human phagocytes. A chloride-dependent mechanism for the conversion of free amino acids into reactive aldehydes by myeloperoxidase. J Biol Chem 1996;271:1861-7.

20. Heinecke JW, Li W, Daehnke HL, Goldstein JA. Dityrosine, a specific marker of oxidation, is synthesized by the myeloperoxidase-hydrogen peroxide system of human neutrophils and macrophages. J Biol Chem 1993;268:4069-77.

21. Witko-Sarsat V, Friedlander $M$, Capeillère-Blandin C, Nguyen-Khoa T, Nguyen AT, Zingraff J, et al. Advanced oxidation protein products as a novel marker of oxidative stress in uremia. Kidney Int 1996;49:1304-13.

22. Iwao Y, Anraku M, Hiraike M, Kawai K, Nakajou K, Kai $\mathrm{T}$, et al. The structural and pharmacokinetic properties of oxidized human serum albumin, advanced oxidation protein products (AOPP). Drug Metab Pharmacokinet 2006;21:140-6.

23. Guo ZJ, Niu HX, Hou FF, Zhang L, Fu N, Nagai R, et al. Advanced oxidation protein products activate vascular endothelial cells via a RAGE-mediated signaling pathway. Antioxid Redox Signal 2008;10:1699-712.

24. Sherman SS, Tobin JD, Hollis BW, Gundberg CM, Roy TA, Plato CC. Biochemical parameters associated with low bone density in healthy men and women. J Bone Miner Res 1992;7:1123-30.

25. Hanasand M, Omdal R, Norheim KB, Gøransson LG, Brede C, Jonsson G. Improved detection of advanced oxidation protein products in plasma. Clin Chim Acta 2012;413:901-6.

26. Joshi M, Patil R. Estimation and comparative study of serum total sialic acid levels as tumor markers in oral cancer and precancer. J Cancer Res Ther 2010;6:263-6.

27. Ham AW, Cormack DH. Cytoplasm and its organelles. In: Ham AW, Cormack DH, editors. Textbook of Histology. 8th ed. Philadelphia: JB Lippincott; 1979. p. 107-65.

28. Baxi BR, Patel PS, Adhvaryu SG, Dayal PK. Usefulness of serum glycoconjugates in precancerous and cancerous diseases of the oral cavity. Cancer 1991;67:135-40.

29. Sydow G. A simplified quick method for determination of sialic acid in serum. Biomed Biochim Acta 1985;44:1721-3.

30. Atik OŞ. Which articles do we prefer to publish? Eklem Hastalik Cerrahisi 2018;29:1.

31. Stahl S, Kanter Y, Karnielli E. Outcome of trigger finger treatment in diabetes. J Diabetes Complications 1997;11:287-90.

32. Griggs SM, Weiss AP, Lane LB, Schwenker C, Akelman E, Sachar K. Treatment of trigger finger in patients with diabetes mellitus. J Hand Surg Am 1995;20:787-9.

33. Takenaka Y, Miki M, Yasuda H, Mino M. The effect of alpha-tocopherol as an antioxidant on the oxidation of membrane protein thiols induced by free radicals generated in different sites. Arch Biochem Biophys 1991;285:344-50.

34. Baynes JW. Role of oxidative stress in development of complications in diabetes. Diabetes 1991;40:405-12.

35. Asayama K, Nakane T, Uchida N, Hayashibe H, Dobashi K, Nakazawa S. Serum antioxidant status in streptozotocininduced diabetic rat. Horm Metab Res 1994;26:313-5.

36. Méndez JD, Xie J, Aguilar-Hernández M, MéndezValenzuela V. Trends in advanced glycation end products research in diabetes mellitus and its complications. Mol Cell Biochem 2010;341:33-41.

37. Salhanick AI, Amatruda JM. Role of sialic acid in insulin action and the insulin resistance of diabetes mellitus. Am J Physiol 1988;255:173-9.

38. Ibrahim MA, Abdulkadir A, Onojah A, Sani L, Adamu A, Abdullahi H. Modulation of sialic acid levels among some organs during insulin resistance or hyperglycemic states. Mol Cell Biochem 2016;411:235-9.

39. Crook M, Lumb P, Andrews V, Swaminathan R. Serum total sialic acid, a reputed cardiovascular risk factor, and its relationship to lipids, plasma fasting insulin, blood 
pressure and body mass index in normal individuals. Clin Sci (Lond) 1998;95:53-7.

40. Witko-Sarsat V, Gausson V, Descamps-Latscha B. Are advanced oxidation protein products potential uremic toxins? Kidney Int Suppl 2003;5:11-4.

41. Piwowar A, Knapik-Kordecka M, Warwas M. AOPP and its relations with selected markers of oxidative/antioxidative system in type 2 diabetes mellitus. Diabetes Res Clin Pract 2007;77:188-92.

42. Gillery P. Advanced glycation end products (AGEs), free radicals and diabetes. J Soc Biol 2001;195:387-90. [Abstract] 